\title{
Preparation of ADP-Glucose with an Enzyme from Arthrobacter simplex
}

\author{
Hiroyasu Kawai, Mizue Kaneko, Kyoko Maejima, \\ Itsuyo Kato and Mari YAMASAKI \\ Department of Food Science and Nutrition, \\ Nara Women's University, \\ Nara 630, Japan
}

Received March 28, 1985

\begin{abstract}
For the purpose of enzymatic preparation of ADP-glucose (ADPG), bacterial screening was performed to find a strain having a high activity of ADPG pyrophosphorylase which catalyzes the synthesis of ADPG from ATP and glucose-1-phosphate. A cell-free extract of Arthrobacter simplex IFO 12069 showed a strong enzyme activity for the synthesis of ADPG, which was isolated from the reaction solution by ion-exchange column chromatography and identified by paper and thin-layer chromatography. The enzyme activity of the bacterium reached a maximum in the late logarithmic phase under aerobic growth conditions. Some factors affecting the ADPG synthesis, e.g. reaction $\mathrm{pH}$, substrate concentrations, divalent cations, inhibitors and activators, were studied with an ammonium sulfate fraction, $30 \sim 50 \%$ saturation as the enzyme preparation.
\end{abstract}

The synthesis of ADP-glucose (ADPG) was first demonstrated in wheat germ ${ }^{1)}$ and subsequently in bacteria to occur through the following reaction catalyzed by ADPG pyrophosphorylase (EC 2.7.7.27).

ATP + glucose-1-phosphate $\rightleftharpoons$

ADPG + inorganic pyrophosphate

It is recognized that the biosynthesis of bacterial glycogen and starch in plants occurs through the enzymatic transfer of glucose from ADPG to an $\alpha-1,4$-glucan primer.

$$
\begin{aligned}
& \text { ADPG }+\alpha-1,4 \text {-glucan } \rightleftharpoons \\
& \alpha \text {-1,4-glucosylglucan }+\mathrm{ADP}
\end{aligned}
$$

Extensive studies on ADPG pyrophosphorylase from different bacteria and plants have shown that the enzyme is allosterically activated by several glycolytic intermediates and inhibited by compounds related to energy metabolism, and the regulatory properties of the enzyme as to the biosynthesis of bacterial glycogen and starch in plants have been established. ${ }^{3)}$ ADPG, a necessary compound for research on the biosynthesis of bacterial glycogen and plant starch, is now exclusively synthesized by a chemical method from adenosine- $5^{\prime}$-monophosphate (AMP) and glucose-1-phosphate as starting materials. ${ }^{4,11}$ ) One of the present authors reported a method for the fermentative production of sugar nucleotides such as UDP glucose, UDP-galactose, UDP- $N$-acetylglucosamine, etc., from uridine- $5^{\prime}$-monophosphate as a starting nucleotide substrate using yeast cells as an enzyme source. ${ }^{5)}$ From the viewpoint of transformation of nucleoside-5'-monophosphates to sugar nucleotides by the microbial method, we attempted to establish a preparative method for obtaining ADPG from AMP and glucose with the use of yeast cells as a catalyst. However, it was not possible to prepare ADPG by a similar fermentation method to that reported previously because of the absence of ADPG pyrophosphorylase activity in yeast cells. Therefore, we tried to prepare ADPG enzymatically from ATP and glucose-1-phosphate as substrates with bacterial ADPG pyrophosphorylase. In this work, we first sought bacterial strains in our laboratory collections 
which had high ADPG pyrophosphorylase activity. As a result, relatively high activities were detected in cell-free extracts of some Arthrobacter species, among which A. simplex IFO $12069^{\circ}$ was found to have the highest activity. The preparation of ADPG from ATP and glucose-1-phosphate with a cellfree extract of the bacterium was performed in order to isolate and identify the reaction product. The optimal culture conditions for the bacterium for the enzyme formation were also investigated as well as several factors affecting the ADPG synthesis with a partially purified enzyme; the effects of reaction $\mathrm{pH}$, substrate concentrations, divalent cations as cofactors, and glycolytic intermediates and inorganic phosphate as stimulators and an inhibitor, respectively.

\section{MATERIALS AND METHODS}

Chemicals. ATP and glucose-1-phosphate were purchased from Boehringer Mannheim, and fructose-1,6diphosphate, fructose-6-phosphate, glucose-6-phosphate, phosphoenolpyruvate, ribose-5-phosphate, ADP, ADPG and AMP were from Sigma Chemical Company. All other chemicals were analytical grade reagents.

Cultivation of bacteria. All bacterial strains from the Faculty of Agriculture, Kyoto University, and the Institute for Fermentation, Osaka, were maintained on agar slants containing $1 \%$ glucose, $0.6 \%$ yeast extract, $1.1 \% \mathrm{~K}_{2} \mathrm{HPO}_{4}$ and $0.85 \% \mathrm{KH}_{2} \mathrm{PO}_{4}, \mathrm{pH} 7.0$. The bacteria were grown for $24 \mathrm{hr}$ at $30^{\circ} \mathrm{C}$ on a reciprocal shaker with $80 \mathrm{ml}$ of the above medium in $500 \mathrm{ml}$-shaking flasks. The inoculum was $5 \mathrm{ml}$ of a $24 \mathrm{hr}$-culture in a test tube. The cells were harvested by centrifugation at $12,000 \times g$ at $0^{\circ} \mathrm{C}$, washed twice with $0.85 \% \mathrm{NaCl}$ and stored at $-20^{\circ} \mathrm{C}$.

Preparation of cell-free extracts and ammonium sulfate fractionation. Thawed cells were suspended in 4 volumes of a buffer containing $0.05 \mathrm{M}$ Tris- $\mathrm{HCl}, \mathrm{pH} 7.5$, and $0.05 \% \beta$ mercaptoethanol, and disrupted by sonication (Kaijodenki ultrasonic oscillator, $20 \mathrm{kHz}$ ) for $10 \mathrm{~min}$ at $0 \sim 5^{\circ} \mathrm{C}$, followed by centrifugation at $12,000 \times g$ for $15 \mathrm{~min}$. The supernatant solution was dialyzed overnight against $0.01 \mathrm{~m}$ Tris- $\mathrm{HCl}, \mathrm{pH} 7.5$, containing $0.05 \% \beta$ mercaptoethanol, and the dialyzed extract was used as a cell-free extract. To the cell-free extract of Arthrobacter simplex, solid ammonium sulfate was added to $30 \%$ saturation, followed by stirring for $15 \mathrm{~min}$ at $0^{\circ} \mathrm{C}$. The precipitate was removed by centrifugation at $12,000 \times g$ for $15 \mathrm{~min}$ and the supernatant solution was brought to
$50 \%$ saturation with ammonium sulfate. The resulting precipitate was obtained by centrifugation and dissolved in $0.05 \mathrm{M}$ Tris- $\mathrm{HCl}, \mathrm{pH} 7.5$, containing $0.05 \% \beta$-mercaptoethanol, followed by dialysis overnight against the same buffer.

Assay of enzyme activity. The ADPG pyrophosphorylase activity of bacterial cell-free extracts was assayed as to ADPG synthesis from ATP and glucose-1phosphate. The reaction mixture containing $5 \mu \mathrm{mol}$ of ATP, $10 \mu \mathrm{mol}$ of glucose-1-phosphate, $100 \mu \mathrm{mol}$ of Tris$\mathrm{HCl}, \mathrm{pH} 8.3,12.5 \mu \mathrm{mol}$ of potassium fluoride, $1.5 \mu \mathrm{mol}$ of fructose-6-phosphate, $10 \mu \mathrm{mol}$ of $\mathrm{MgCl}_{2}$ and the enzyme, in a total volume of $1.0 \mathrm{ml}$, was incubated at $37^{\circ} \mathrm{C}$. The reaction was terminated by heating the reaction mixture in a boiling water bath for $3 \mathrm{~min}$. The denatured enzyme protein was precipitated by centrifugation and the supernatant solution was subjected to ADPG analysis by high performance liquid chromatography on a column of CDR-10 (Mitsubishi Kasei Kogyo Co., Ltd.) at a column temperature of $60^{\circ} \mathrm{C}$. The elution buffer was $3 \mathrm{M}$ acetic acid-ammonium acetate, $\mathrm{pH} 3.85$ and $\mathrm{pH}$ 4.5. One unit of enzyme activity was defined as the amount of enzyme that catalyzed the formation of $1 \mu \mathrm{mol}$ of ADPG in $1 \mathrm{hr}$ under the reaction conditions described above. Specific activity was expressed as units per $\mathrm{mg}$ of protein.

Isolation and identification of nucleotides. Paper chromatography was carried out with $95 \%$ ethanol-1 M ammonium acetate $(5: 2, \mathrm{pH} 7.5), 95 \%$ ethanol- $1 \mathrm{~m}$ ammonium acetate $(5: 2, \mathrm{pH} 3.8)$ and isobutyric acid- $1 \mathrm{M}$ ammonia- 0.1 M EDTA $(10: 6: 0.6)$ as developing solvents. Thin-layer chromatography was carried out on polyethyleneimine-cellulose plates with $0.5 \mathrm{M}$ ammonium sulfate as the developing solvent. Ion-exchange column chromatography for nucleotides was performed with a column of Dowex $1 \times 4$, formate form, using a formic acidammonium formate system as the eluting solvent. Protein was determined by the method of Lowry et al. ${ }^{6}$

\section{RESULTS AND DISCUSSION}

\section{Screening of bacteria having high ADPG pyro- phosphorylase activity}

The occurrence of the enzyme, ADPG pyrophosphorylase, has been reported in a variety of bacteria such as Escherichia coli B, E. aurescens, Citrobacter freundii, Aerobacter aerogenes, A. cloacae, Proteus vulgaris, Agrobacterium tumefaciens, Ervinia carotovora, Arthrobacter viscosus, Serratia marcesens, Salmonella typhimurium, Micrococcus lysodeikticus, Rhodopseudomonas capsulata, Rhodospirillum rubrum, etc. ${ }^{3)}$ The enzyme activity 
of cell-free extracts of these bacteria as to ATP synthesis from ADPG and inorganic pyrophosphate, i.e. the pyrophosphorolysis of ADPG, varied considerably from genus to genus, and the amount of ATP formed ranged from 0.012 to $9.24 \mu \mathrm{mol} / \mathrm{mg}$ protein $/ \mathrm{hr}$ as calculated from the data reported so far. ${ }^{79}$ ) Excluding photosynthetic bacteria, the highest activity was found in Arthrobacter viscosus NRRL B1973, with which $8.76 \mu \mathrm{mol} / \mathrm{mg}$ protein/hr of ATP was formed under the specific reaction conditions. ${ }^{10)}$ Therefore, we investigated several Arthrobacter species as well as some strains of other genera which have high ADPG pyrophosphorylase activity as to ADPG synthesis from ATP and glucose-1phosphate. As shown in Table I, relatively high enzyme activity was found in some species of the genus Arthrobacter, of which $A$. simplex showed the highest activity, followed

TABle I. Distribution of ADPG Pyrophosphorylase ACTIVITY IN BACTERIA

\begin{tabular}{lc}
\hline \multicolumn{1}{c}{ Bacteria } & $\begin{array}{c}\text { ADPG formed } \\
(\mu \mathrm{mol} / \mathrm{mg}\end{array}$ \\
& protein $/ \mathrm{hr}^{a}$ \\
\hline Proteus vulgaris (IFO 3167) & 0 \\
Achromobacter aceris (IFO 3116) & 0 \\
Bacillus subtilis (IFO 3007) & 0 \\
Agrobacterium tumefaciens & 0.044 \\
(IAM 1037) & \\
Micrococcus glutamicus & \\
(ATCC 13060) & 0 \\
Staphylococcus aureus (IFO 3060) & 0 \\
Sarcina lutea (IAM 1099) & 0 \\
Brevibacterium ammoniagenes & 0.002 \\
(IFO 12071) & 0 \\
Pseudomonas fragi (IFO 3458) & 0 \\
Aerobacter aerogenes (AKU 0022) & 0 \\
Escherichia coli (AKU 0001) & 0.419 \\
Arthrobacter simplex (IFO 12069) & 0 \\
Arthrobacter globiformis (IFO 3062) & 0.295 \\
Arthrobacter aurescens (IFO 12136) & 0.178 \\
Arthrobacter oxydans (IFO 12138) & 0.208 \\
Arthrobacter pascens (IFO 12139) & 0.229 \\
Arthrobacter ureafaciens (IFO 12140) & 0 \\
Arthrobacter citreus (IFO 12957) & 0 \\
Arthrobacter tumescens (IFO 12960) & 0 \\
Arthrobacter viscosus (IFO 13497) & \\
\hline
\end{tabular}

a The enzyme activity was assayed under the reaction conditions given under METHODS using a cell-free extract of each organism. by $A$. aurescens, $A$. ureafaciens, $A$. pascens and $A$. oxydans. No enzyme activity was detected in the cell-free extracts from E. coli, Aerobacter aerogenes and Arthrobacter viscosus, which were reported to have fairly good activity. ${ }^{7}$ 9) The present results suggest that $A$. simplex is an efficient bacterium for the enzymatic preparation of ADPG from ATP and glucose-1phosphate.

\section{Isolation and identification of the reaction product}

In order to isolate and identify the reaction product, ADPG, in the reaction solution, $20 \mathrm{ml}$ of the reaction mixture for the enzyme assay described under MeTHODs was incubated for $60 \mathrm{~min}$ at $37^{\circ} \mathrm{C}$ with $84 \mathrm{mg}$ enzyme protein of the cell-free extract of $A$. simplex. The reaction was terminated by heating the reaction solution in a boiling water bath for $3 \mathrm{~min}$ followed by immediate cooling. The reaction solution was centrifuged at $2000 \times g$ for $15 \mathrm{~min}$ and the supernatant solution adjusted to $\mathrm{pH} 4.0$ with $\mathrm{HCl}$. One gram of activated charcoal was added to the supernatant solution $(17 \mathrm{ml})$ followed by stirring for $60 \mathrm{~min}$ at $0^{\circ} \mathrm{C}$. Then the charcoal was collected by filtration, washed with water and suspended in $50 \mathrm{ml}$ of $50 \%$ ethanol $-1.4 \%$ ammonium hydroxide solution. After stirring for $60 \mathrm{~min}$ at $0^{\circ} \mathrm{C}$, the charcoal was filtered off and the filtrate was concentrated to about $5 \mathrm{ml}$ by evaporation under reduced pressure at $40^{\circ} \mathrm{C}$. The concentrate was adjusted to $\mathrm{pH} 8.0$ with ammonia and applied on a column of Dowex

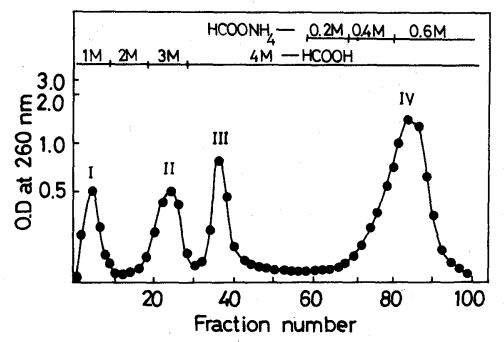

FIG. 1. Separation of ADPG by Ion-exchange Column Chromatography.

Ion-exchanger, Dowex $1 \times 4$, formate form; column size, $1 \times 10 \mathrm{~cm}$; flow rate, $2 \mathrm{ml} / \mathrm{min}, 5 \mathrm{ml} /$ tube. I, AMP; II, ADPG; III, ADP; IV, ATP. 
$1 \times 4$, formate form. The adsorbed nucleotides were eluted with a formic acid-ammonium formate system by increasing the concentration of formic acid. Figure 1 shows the elution pattern of the ultraviolet absorbing compounds. Four major fractions were separated, and the compounds in each fraction were identified as AMP, ADPG, ADP and ATP, in order of elution, from their $R f$ values on paper and thin-layer chromatography, and from their retention times on high performance liquid chromatography. The molar ratio of these compounds, calculated as adenosine from the absorbance at $260 \mathrm{~nm}$, was $1: 1.6: 2.0: 5.4$, respectively. The second fraction corresponding to ADPG was treated with activated charcoal, followed by elution with an ammoniacal ethanol solution as described above. The final yield of ADPG was $5.2 \mu \mathrm{mol}$. Large amounts of AMP and ADP were also formed from ATP under the reaction conditions through the catalysis of ATPase and nucleoside diphosphatase present in the cellfree extract of the bacterium. It seems from Fig. 1 that ADPG can be separated satisfactorily from AMP, ADP and ATP by using Dowex $1 \times 4$, formate form, with a formic acid-ammonium formate system as the eluting solvent.

\section{Effect of culture conditions on enzyme activity}

It is presumed that the ADPG pyrophosphorylase activity of A. simplex is affected by the growth phase of the cells. Therefore, the effect of cultivation time on the enzyme activity was investigated using the same medium as described under METHODS. It was found that the cells of a $24 \mathrm{hr}$-culture corresponding to the late logarithmic growth phase showed maximum activity, and further cultivation led to a gradual decrease in the enzyme activity (data not shown). Then, the effect of aeration on the enzyme activity was investigated. The enzyme activity of the cells tended to decrease as the volume of liquid culture medium was increased stepwise from $50 \mathrm{ml}$ to $100 \mathrm{ml}, 200 \mathrm{ml}$ and $300 \mathrm{ml}$ in a $500 \mathrm{ml}-$ shaking flask (data not shown). It seems from these results that aerobic growth conditions favor the formation of ADPG pyrophosphorylase in the bacterium.

\section{Factors affecting the ADPG synthesis}

More than $95 \%$ of the enzyme activity in the cell-free extract of $A$. simplex was found in a $30 \sim 50 \%$ ammonium sulfate saturated fraction. Therefore, we investigated several factors which affect the synthesis of ADPG with the above fraction as the enzyme preparation with a specific activity of 1.46 units per $\mathrm{mg}$ of protein.

a) Time course of reaction. ADPG pyrophosphorylase catalyzes a reversible reaction as described previously. The time course of the synthesis of ADPG as well as that of the pyrophosphorolysis of ADPG was studied. As shown in Fig. 2a, the synthesis of ADPG from ATP and glucose-1-phosphate reached a maximum in $30 \mathrm{~min}$, and then ADPG began to decrease on further incubation. The maximum amount of ADPG accumulated was $1.7 \mu \mathrm{mol} / \mathrm{ml}$, the molar yield based on ATP being $34 \%$. On the other hand, the formation of ATP from ADPG and inorganic pyrophosphate proceeded almost linearly up to $60 \mathrm{~min}$ as shown in Fig. 2b. The rate of ADPG synthesis from ATP and glucose-1phosphate was much higher than that of the pyrophosphorolysis of ADPG under the reaction conditions, indicating that the reaction

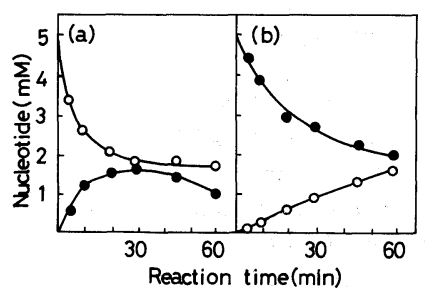

FIG. 2. Time Courses of Synthesis and Pyrophosphorolysis of ADPG.

The reaction mixtures contained $5 \mathrm{~mm}$ ATP, $10 \mathrm{~mm}$ glucose-1-phosphate in (a), and $5 \mathrm{~mm}$ ADPG, $10 \mathrm{~mm}$ inorganic pyrophosphate in (b), other than $100 \mathrm{~mm}$ Tris$\mathrm{HCl}, \mathrm{pH} 8.3,12.5 \mathrm{~mm}$ potassium fluoride, $1.5 \mathrm{~mm}$ fructose-6-phosphate, $10 \mathrm{mM} \mathrm{MgCl}_{2}$ and the enzyme $(3.5 \mathrm{mg}$ as protein) in a total volume of $1.0 \mathrm{ml}$ ATP $;-0-$, ADPG. 


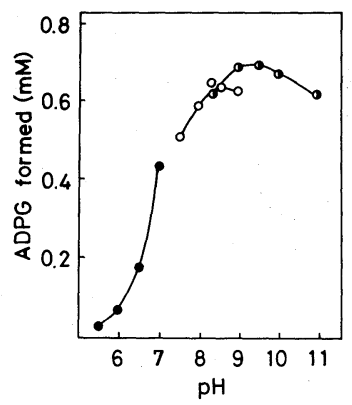

Fig. 3. Effect of pH on ADPG Synthesis.

The reaction system was the same as in Fig. 2a except that the buffer solution was changed as follows. The incubations were carried out for $10 \mathrm{~min}$ at $37^{\circ} \mathrm{C}$.

histidine buffer; - $\mathrm{O}-$, Tris- $\mathrm{HCl}$ buffer; - buffer.

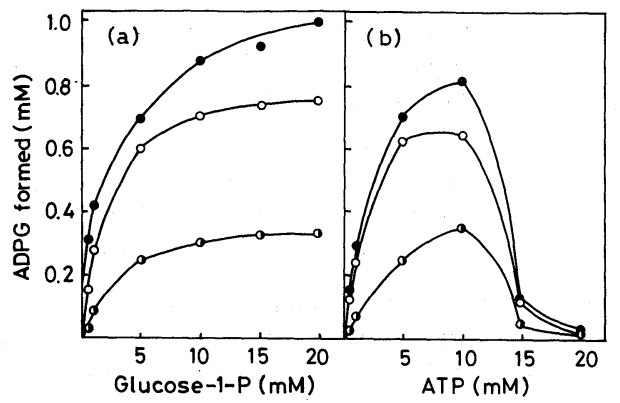

FIG. 4. Effects of Substrate Concentrations on ADPG Synthesis.

The reaction mixtures contained $100 \mathrm{~mm}$ Tris- $\mathrm{HCl}, \mathrm{pH} 8.3$, $12.5 \mathrm{~mm}$ potassium fluoride, $1.5 \mathrm{~mm}$ fructose- 6 -phosphate, $10 \mathrm{mM} \mathrm{MgCl}_{2}$, the enzyme $(3.5 \mathrm{mg}$ as protein) and the indicated amounts of substrates in a total volume of $1.0 \mathrm{ml}$. The incubations were carried out for $10 \mathrm{~min}$ at $37^{\circ} \mathrm{C}$.

(a) ATP: $-\mathrm{O}-1 \mathrm{~mm} ;-\mathrm{O}-, 5 \mathrm{~mm} ;-\bigcirc-10 \mathrm{~mm}$.

(b) Glucose-1-phosphate: $-\mathrm{O}-1 \mathrm{~mm}$; $-\mathrm{O}-, 5 \mathrm{~mm}$; - - $10 \mathrm{~mm}$.

favors the synthesis of ADPG more than the pyrophosphorolysis of ADPG. The amount of ADPG formed from ATP and glucose-1-phosphate and that of ATP formed from ADPG by pyrophosphorolysis were always smaller than the amount of the respective nucleotide substrates consumed. This is probably due to some contaminating enzymes in the enzyme preparation which catalyze the degradation of ADPG and ATP.

b) Effect of $p H$. The effect of $\mathrm{pH}$ on ADPG
Table II. EfFects of Divalent Cations on ADPG PYROPHOSPHORYLASE ACTIVITY

The reaction mixtures contained $5 \mathrm{~mm}$ ATP, $10 \mathrm{~mm}$ glucose-1-phosphate, $100 \mathrm{~mm}$ Tris- $\mathrm{HCl}, \mathrm{pH} 8.3,12.5 \mathrm{~mm}$ potassium fluoride, $1.5 \mathrm{~mm}$ fructose-6-phosphate, $5 \mathrm{~mm}$ divalent cations indicated below, and the enzyme $(0.7 \mathrm{mg}$ as protein) in a total volume of $0.2 \mathrm{ml}$. The incubations were carried out for $10 \mathrm{~min}$ at $37^{\circ} \mathrm{C}$.

\begin{tabular}{cl}
$\begin{array}{c}\text { Divalent cations } \\
\text { added }\end{array}$ & $\begin{array}{c}\text { ADPG formed } \\
(\mathrm{mm})\end{array}$ \\
\hline None & 0 \\
$\mathrm{MgCl}_{2}$ & 0.573 \\
$\mathrm{MnCl}_{2}$ & 0.520 \\
$\mathrm{CoCl}_{2}$ & 0.208 \\
$\mathrm{CaCl}_{2}$ & 0.018 \\
$\mathrm{BaCl}_{2}$ & 0.008 \\
$\mathrm{HgCl}_{2}$ & 0 \\
\hline
\end{tabular}

synthesis is shown in Fig. 3. Maximum activity was observed at about $\mathrm{pH} 9$ in glycine buffer, and $\mathrm{pH} 8 \sim 8.5$ in Tris- $\mathrm{HCl}$, but the activity was decreased below $\mathrm{pH} 7$. It was reported that the $\mathrm{pH}$ optimum for both synthesis and pyrophosphorolysis of ADPG by the enzyme from Arthrobacter viscosus was about pH 10 in glycine buffer. ${ }^{7)}$

c) Effect of substrate concentrations. The effect of the concentrations of ATP and glucose-1-phosphate on the enzyme activity were investigated. As shown in Fig. 4a, the synthesis of ADPG increased with increasing amounts of glucose-1-phosphate in the presence of 1,5 and $10 \mathrm{~mm}$ ATP, and maximum formation of ADPG was observed at $10 \mathrm{~mm}$ ATP and $20 \mathrm{~mm}$ glucose-1-phosphate in the presence of $10 \mathrm{~mm} \mathrm{Mg}^{2+}$. On the other hand, the enzyme activity was strongly inhibited by ATP at more than $15 \mathrm{~mm}$ in the presence of 1,5 and $10 \mathrm{~mm}$ glucose-1-phosphate as shown in Fig. 4b. This was found to be due to the shortage of $\mathrm{Mg}^{2+}$ in the reaction mixture, and the activity was recovered by increasing the concentration of $\mathrm{Mg}^{2+}$ from $10 \mathrm{~mm}$ to $20 \mathrm{~mm}$. This indicates that the maximal activity of ADPG pyrophosphorylase is highly dependent on the $\mathrm{ATP}-\mathrm{Mg}^{2+}$ ratio in the reaction system.

d) Effects of divalent cations. The require- 


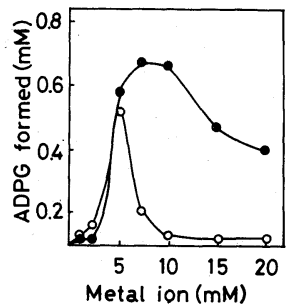

FIG. 5. Effects of $\mathrm{Mg}^{2+}$ and $\mathrm{Mn}^{2+}$ Concentrations on ADPG Synthesis.

The reaction mixtures contained $5 \mathrm{mM}$ ATP, $10 \mathrm{~mm}$ glucose-1-phosphate, $100 \mathrm{~mm}$ Tris- $\mathrm{HCl}, \mathrm{pH} 8.3,12.5 \mathrm{~mm}$ potassium fluoride, $1.5 \mathrm{~mm}$ fructose- 6 -phosphate, the enzyme $(3.5 \mathrm{mg}$ as protein) and the indicated amounts of $\mathrm{MgCl}_{2}$ or $\mathrm{MnCl}_{2}$ in a total volume of $1.0 \mathrm{ml}$. The incubations were carried out for $10 \mathrm{~min}$ at $37^{\circ} \mathrm{C}$. - $\mathrm{MgCl}_{2} ;-\mathrm{O}-, \mathrm{MnCl}_{2}$.

ment of divalent cations such as $\mathrm{Mg}^{2+}$ and $\mathrm{Mn}^{2+}$ for bacterial ADPG pyrophosphorylase has already been reported. So, the effects of some divalent cations on the activity of the $A$. simplex enzyme were investigated. As shown in Table II, $\mathrm{Mg}^{2+}$ was the most effective metal ion and $\mathrm{Mn}^{2+}$ was almost as effective as $\mathrm{Mg}^{2+}$. The activity in the presence of $\mathrm{Co}^{2+}$ was about one-third of that observed with $\mathrm{Mg}^{2+} \cdot \mathrm{Ca}^{2+}, \mathrm{Ba}^{2+}$ and $\mathrm{Hg}^{2+}$ had almost no effect. Figure 5 shows that the optimum $\mathrm{Mg}^{2+}$ level is $7 \sim 8 \mathrm{~mm}$ at substrate concentrations of $5 \mathrm{~mm}$ ATP and $10 \mathrm{~mm}$ glucose-1-phosphate, and an amount of $\mathrm{Mg}^{2+}$ higher than $8 \mathrm{~mm}$ caused a gradual decrease in the enzyme activity. On the other hand, the maximum activity was found in the presence of $5 \mathrm{mM} \mathrm{Mn}^{2+}$, but the activity was strongly inhibited by $10 \mathrm{~mm} \mathrm{Mn}{ }^{2+}$. This suggests that the kinetics of ADPG synthesis in the presence of $\mathrm{Mg}^{2+}$ are different from those of the reaction in the presence of $\mathrm{Mn}^{2+}$.

e) Effects of glycolytic intermediates and related compounds. It was reported that ADPG pyrophosphorylases from bacteria are activated by various glycolytic intermediates. ${ }^{3)}$ For example, the enzyme from Enterobacteria is accelerated primarily by fructose-1,6diphosphate, the enzyme from Arthrobacter viscosus by fructose-6-phosphate, and the enzyme from Agrobacterium tumefaciens and

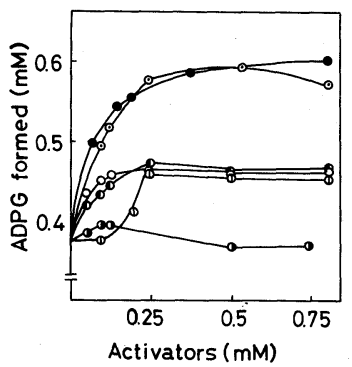

FIG. 6. Effects of glycolytic Intermediates on ADPG Synthesis.

The reaction mixtures contained $5 \mathrm{~mm}$ ATP, $10 \mathrm{~mm}$ glucose-1-phosphate, $100 \mathrm{~mm}$ Tris- $\mathrm{HCl}, \mathrm{pH} 8.3,12.5 \mathrm{~mm}$ potassium fluoride, $10 \mathrm{~mm} \mathrm{MgCl}_{2}$, the enzyme $(3.5 \mathrm{mg}$ as protein) and the indicated amounts of compounds in a total volume of $1.0 \mathrm{ml}$. The incubations were carried out for $10 \mathrm{~min}$ at $37^{\circ} \mathrm{C}$. - - - , fructose-6-phosphate; $-\odot-$, glucose-6-phosphate; - $\mathrm{O}-$, phosphoenolpyruvate; -D-, ribose-5-phosphate; - (1)-, pyruvate; - fructose-1,6-diphosphate.

Table III. EfFect of InORganic Phosphate on ADPG Pyrophosphorylase Activity in the Presence AND ABSENCE OF Fructose-6-PHOSPHATE

The reaction mixtures contained $5 \mathrm{~mm}$ ATP, $10 \mathrm{~mm}$ glucose-1-phosphate, $100 \mathrm{~mm}$ Tris- $\mathrm{HCl}, \mathrm{pH} 8.3,12.5 \mathrm{~mm}$ potassium fluoride, $10 \mathrm{mM} \mathrm{MgCl}$, the indicated amount of inorganic phosphate, $1.5 \mathrm{~mm}$ fructose-6-phosphate ( $\mathrm{F}$ $6-\mathrm{P})$ and the enzyme $(0.7 \mathrm{mg}$ as protein $)$ in a total volume of $0.2 \mathrm{ml}$. The incubations were carried out for $10 \mathrm{~min}$ at $37^{\circ} \mathrm{C}$.

\begin{tabular}{ccc}
\hline \multirow{2}{*}{$\begin{array}{c}\text { Concentration } \\
\text { of } \mathrm{KH}_{2} \mathrm{PO}_{4}(\mathrm{mM})\end{array}$} & \multicolumn{2}{c}{ ADPG formed (mM) } \\
\cline { 2 - 3 } & F-6-P absent & F-6-P present \\
\hline 0 & $0.360(100)$ & $0.633(100)$ \\
0.25 & $0.320(89)$ & $0.646(102)$ \\
0.5 & $0.266(74)$ & $0.583(92)$ \\
0.75 & $0.200(56)$ & $0.563(89)$ \\
1.0 & $0.153(43)$ & $0.566(89)$ \\
1.5 & $0.113(31)$ & $0.576(91)$ \\
2.0 & $0.086(24)$ & $0.453(72)$ \\
\hline
\end{tabular}

The values in parentheses are the relative percentages of residual activities when the activity in the absence of inorganic phosphate was taken as $100 \%$.

Rhodospirillum rubrum by pyruvate, respectively. Figure 6 shows the effects of various glycolytic intermediates and related compounds on the rate of ADPG synthesis by the $A$. simplex enzyme. Fructose-6- and glucose-6-phosphate showed the best activa- 
tion, while phosphoenolpyruvate, pyruvate and ribose-5-phosphate showed lesser effects. Fructose-1,6-diphosphate had no stimulatory effect. On the other hand, inorganic phosphate strongly inhibited the synthesis of ADPG, which appeared to be overcome in the presence of a small amount of fructose-6-phosphate as shown in Table III. The enzymatic behavior as to this activator, fructose-6-phosphate, and inhibitor, inorganic phosphate, of $A$. simplex seems to be similar to that of $A$. viscosus reported previously. ${ }^{10)}$

The chemical method for the synthesis of ADPG involves the treatment of AMP with diphenylphosphochloridate in dioxane in the presence of tributylamine to synthesize adenosine-5'-diphenylpyrophosphate, which is then reacted with tri- $n$-butylammonium glucose-1-phosphate in pyridine overnight at room temperature. ${ }^{11)}$ The preparation of these starting substrates for this procedure from AMP and glucose-1-phosphate seems to be too time-consuming, although the final yield of ADPG is reported to be as high as $80 \%$. The enzymatic method for the ADPG synthesis, on the other hand, requires a specific enzyme, ADPG pyrophosphorylase. The present work has shown that Arthrobacter simplex IFO 12069 serves as a good enzyme source for the preparation of ADPG from ATP and glucose1-phosphate as starting materials which are readily available at a moderate price now. With an ammonium sulfate fraction (30 $50 \%$ saturation) of the cell-free extract of $A$. simplex, ADPG was formed in an about $34 \%$ yield in $30 \mathrm{~min}$ under the reaction conditions as shown in Fig. 2a, which seemed to be almost optimal in terms of reaction $\mathrm{pH}$, concentrations of $\mathrm{Mg}^{2+}$ and fructose-6phosphate added as activators, but not the concentrations of substrates. The concentrations of substrates, especially that of ATP, were very influential in the synthesis of ADPG in relation to the concentration of $\mathrm{Mg}^{2+}$. Further experiments to determine the optimal substrate concentrations are now in progress to obtain better yields of ADPG based on ATP. The addition of inorganic pyrophosphatase, which converts inorganic pyrophosphate into inorganic phosphate, to the reaction system employed in the present work will favor the synthesis of ADPG. This enzymatic method will also be applicable to the preparation of radioactive ADPG on a small scale with the use of radioactive starting substrates.

Acknowledgment. The authors wish to express their sincere thanks to Professor Kinji Endo, Department of Food Science and Nutrition, Nara Women's University, for his valuable discussion and support on this work.

\section{REFERENCES}

1) J. Espada, J. Biol. Chem., 237, 3577 (1962).

2) L. Shen and J. Preiss, Biochem. Biophys. Res. Commun., 17, 424 (1964).

3) J. Preiss, "Advances in Enzymology and Related Areas of Molecular Biology," ed. by A. Meister, Wiley, New York, 1978, pp. 317 381.

4) N. K. Kochetkov and V. N. Shibaev, Adv. Carb. Chem. Biochem., 28, 344 (1973).

5) H. Kawai, Hakkokogaku Kaishi, 56, 139 (1978).

6) O. H. Lowry, N. J. Rosebrough, A. L. Farr and R. J. Randall, J. Biol. Chem., 193, 265 (1951).

7) L. Shen and J. Preiss, J. Biol. Chem., 240, 2334 (1965).

8) L. Eidels, P. L. Edelmann and J. Preiss, Arch. Biochem. Biophys., 140, 60 (1970).

9) G. Ribereau-Gayon, A. Sabraw, C. Lammel and J. Preiss, Arch. Biochem. Biophys., 142, 675 (1971).

10) L. Shen and J. Preiss, Arch. Biochem. Biophys., 116, 375 (1966).

11) A. M. Michelson, Biochim. Biophys. Acta, 91, 1 (1964). 